\title{
MANFAAT OLAH RAGA BAGI WANITA HAMIL
}

\author{
4 \\ Oleh: Suharjana \\ Dosen Jurusan Pendidikan Kesehatan dan Rekreasi FIK UNY
}

\section{Abstrak :}

Sebagian besar anggota masyarakat masih mengalami kebingungan atau keraguan akan perlunya wanita hamil berolahrga. Olahraga tidak berbahaya bagi ibu maupun calon anak. Selama tidak ada larangan tidak diperbolehkan berolahraga dari ahli kandungan atau dokter, berarti kondisi ibu, dan calon anak yang dikandungnya dalam keadaan normal, yang berarti seorang ibu yang sedang hamil tidak perlu ragu-ragu untuk berolahraga

Setiap orang akan mempunyai pengalaman dan memberikan reaksi yang berbeda terhadap kehamilan yang mereka alami. Pengalaman dan reaksi wanita hamil dipengaruhi oleh beberapa faktor, yakni kepribadian, status gizi, pola hidup, hubungannya dengan orang tua dan keluarganya serta sikapnya terhadap kemungkinan hadirnya seorang anak. Kehamilan adalah suatu fase krisis maturasi, yang konsekuensinya tidak mungkin untuk dihindari. Usaha yang dapat dilakukan hanyalah mengurangi derita yang akan dialami.

Salah satu cara yang dapat ditempuh guna mengurangi derita kehamilan dan persalinan adalah dengan melakukan olahraga atau latihan. Sebelum melakukan dan menentukan macam latihan, sebaiknya didahului dengan konsultasi pada dokter atau ahli fisiologi. Di dalam melakukan latihan, wanita hamil harus secara cermat membaca sinyal-sinyal yang diberikan oleh tubuhnya. Jika sekiranya latihan tersebut membuatnya kelelahan, maka intensitas atau durasinya perlu diturunkan. Jika ternyata gerakangerakan dalam latihan tersebut terlalu sulit untuk dilakukan, maka dapat diganti dengan latihan yang lain, yang lebih sederhana. Ada beberapa macam olahraga yang dapat dipilih, yakni jogging, jalan cepat, senam atau renang terutama gaya dada.

Kata Kunci: wanita hamil, perubahan fisik

Setiap manusia akan mengalami tiga hal penting, yakni lahir, hidup dan mati. Lebih khusus, wanita secara kodrat dilahirkan juga untuk melahirkan, termasuk hamil. Secara umum, tidak akan ada orang yang ingin mengalami rasa sakit, ketidaknyamanan dan kerepotan. Demikian juga para wanita. Meskipun sebagian besar wanita menginginkan hamil, melahirkan dan mempunyai anak, namun tidak seorangpun yang menginginkan mengalami derita rasa sakit dan ketidaknyamanan karena kehamilan dan persalinan. Lebih jauh, meskipun kehamilan dan persalinan akan membawa konsekuensi yang sudah 
diperhitungkan atau sudah diketahui sebelumnya, namun tetap saja merupakan tugas atau beban yang berat.

Karena kehamilan dan persalinan memang diharapkan, sementara derita atau konsekuensinya tidak mungkin untuk dihindari, maka yang dapat dilakukan adalah mengurangi deritanya dan memperlancar proses-proses yang akan berlangsung selama masa kehamilan dan persalinan. Salah satu usaha yang dapat ditempuh adalah dengan melakukan olahraga.

Mungkin sudah ketinggalan zaman untuk membicarakan olahraga dan kehamilan di masa yang sudah "maju" ini. Tapi ternyata sebagian besar anggota masyarakat masih mengalami kebingungan atau keraguan. Hal itu muncul karena adanya dua pendapat yang saling bertentangan. Pendapat pertama mengatakan bahwa kegiatan olahraga bagi wanita hamil adalah berbahaya baik bagi wanita itu sendiri maupun bagi bayi yang dikandungnya. Sehingga bagi para wanita hamil dilarang untuk melakukan olahraga dan harus menambah porsi istirahatnya. Sementara pendapat yang lain mengatakan bahwa para wanita hamil perlu melakukan olahraga untuk memperlancar proses persalinan.

Selama tidak ada larangan berolahraga dari ahli kandungan atau dokter, berarti kondisi ibu, dan calon anak yang dikandungnya dalam keadaan normal, yang berarti seorang ibu yang sedang hamil tidak perlu ragu-ragu untuk berolahraga. Sadoso Sumosardjuno (1988) menyatakan bahwa wanita hamil sangat dianjurkan untuk tetap melakukan kegiatan seharihari secara rutin, termasuk olahraga. Menurut Wells (1985), selama kehamilan normal, tidak ada bukti yang menyatakan adanya kontraindikasi terhadap latihan. Nampaknya ibu dan janin sudah dilengkapi bekal sedemikian rupa, sehingga mampu mengatasi sedikit penurunan reserve jantung dan aliran darah ke uterus yang akan dialami karena latihan.

Setiap wanita yang hamil akan mengalami perubahan-perubahan fisiologis dan psikhologis yang akan mempengaruhi seluruh sistem di dalam tubuhnya. Perubahan-perubahan tersebut dimulai sejak terjadinya konsepsi, bahkan sebelum mereka menyadari bahwa ada sesuatu yang menempati rahimnya. Hal itu akan terus berlangsung selama masa kehamilan, bahkan sebagian efek penyesuaian fisiologis belum akan kembali ke kondisi normal, hingga sekitar minggu ke enam setelah persalinan.

Tidak semua wanita akan mempunyai pengalaman hamil yang sama. Mereka akan mempunyai reaksi fisiologis dan psikologis yang berbeda. Reaksi wanita terhadap kehamilan yang dialami dan bagaimana mereka mengatasi masalah-masalah yang timbul karena kehamilan dipengaruhi oleh faktor-faktor kepribadian, pola hidup, hubungan dengan orang tua dan keluarga, perasaan dan tanggapannya terhadap hadirnya anak dan tingkat kesegaran jasmaninya (Sandelowski, 1981: 61).

Beberapa wanita hamil mengalami kesulitan-kesulitan fisik. Semenetara yang lain merasakan bahwa kehamilan menimbulkan rasa cemas. Pada sebagian wanita, kehamilan akan menyebabkan gejolak emosional yang tinggi, yang akan menurun secara bertahap dan akhirnya akan kembali ke normal. Namun demikian, sebagian besar wanita menyadari bahwa kehamilan merupakan proses tumbuh kembang lanjut dan merupakan kodrat yang akan berlangsung secara alami. Pengalaman yang sekilas nampak saling bertentangan 
tersebut, ternyata semua mengandung kebenaran. Hal itu juga didukung oleh Stewart (1983: 44) yang menyebut kehamilan sebagai krisis maturasi.

Olahraga yang diperuntukkan bagi para wanita hamil tentu saja berbeda dengan olahraga yang diperuntukkan bagi wanita yang tidak hamil dan juga yang lain. Untuk selanjutnya, tulisan ini akan membahas tentang perubahan-perubahan yang akan terjadi selama masa kẹamilan dan pengaruh olahraga pada kehamilan.

\section{PERUBAHAN FISIK YANG MENYERTAI KEHAMILAN}

\section{Perubahan secara umum}

Secara umum, tidak ada harga yang pasti berapa besar pertambahan berat badan yang menyertai kehamilan. Menurut Sekolah Kebidanan dan Ginekologi Amerika, berat badan akan naik sekitar 22-26 pond, yang perlu diperhatikan di sini adalah bahwa penambahan berat badan yang berlebihan karena lemak akan sulit dihilangkan, sehingga sebaiknya dihindari.

Faktor-faktor yang mempengaruhi penambahan berat badan adalah usia, status gizi dan aktivitas calon ibu. Sebaiknya, penambahan berat badan pada akhir trimester pertáma berkisar antara 2-4 pond, sementara berat janin masih sekitar satu ons. Selanjutnya, penambahan berat badan satu pond per minggu.

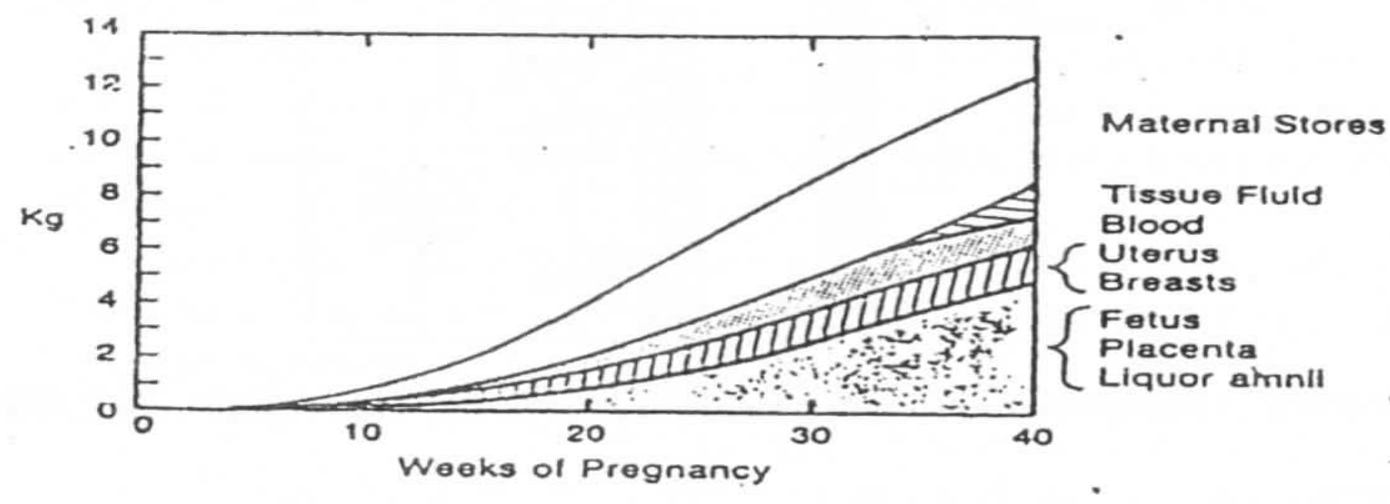

Gambar 1. Distribusi Penambahan Berat Badan pada Kehamilan Normal (Wells 1998:174)

\section{Perubahan sistem respirasi}

Bertambahnya aliran darah ke uterus dan tingginya kadar progesterone, menyebabkan penurunan tahanan sistematis vascular. Dengan bertambahnya usia kehamilan, rongga perut akan mengalami perluasan dengan mendesak diagram ke atas dan memaksa susunan ruas-ruas tulang belakang menjadi lebih lordosis. Hal tersebut bertujuan untuk memberi ruang yang cukup bagi janin dan juga inspirasi yang dalam bagi ibu/calon ibu. 
Kecepatan respirasi tidak berubah dengan berlangsungnya kehamilan, sementara volume tidal akan mengalami peningkatan secara bertahap. Naiknya volume tidal ini disebabkan oleh kecepatan respirasi dan volume respirasi/menit yang tetap. Kenaikan volume tidal tersebut akan menyebabkan perubahan pada beberapa volume lain. Sebagai contoh, meskipun kapasitas vital konstan, tapi volume reserve inspirasi dan volume reserve ekspirasi turun. Hal tersebut akan diperjelas oleh rumus: volume respirasi $/$ menit $=$ volume tidal $\times$ kecepatan respirasi. Volume residual juga naik. Hiperventilasi juga akan terjadi sebagai akibat tingginya kadar $\mathrm{CO}_{2}$ di dalam alveoli dan dalam darah (Wells, 1985).

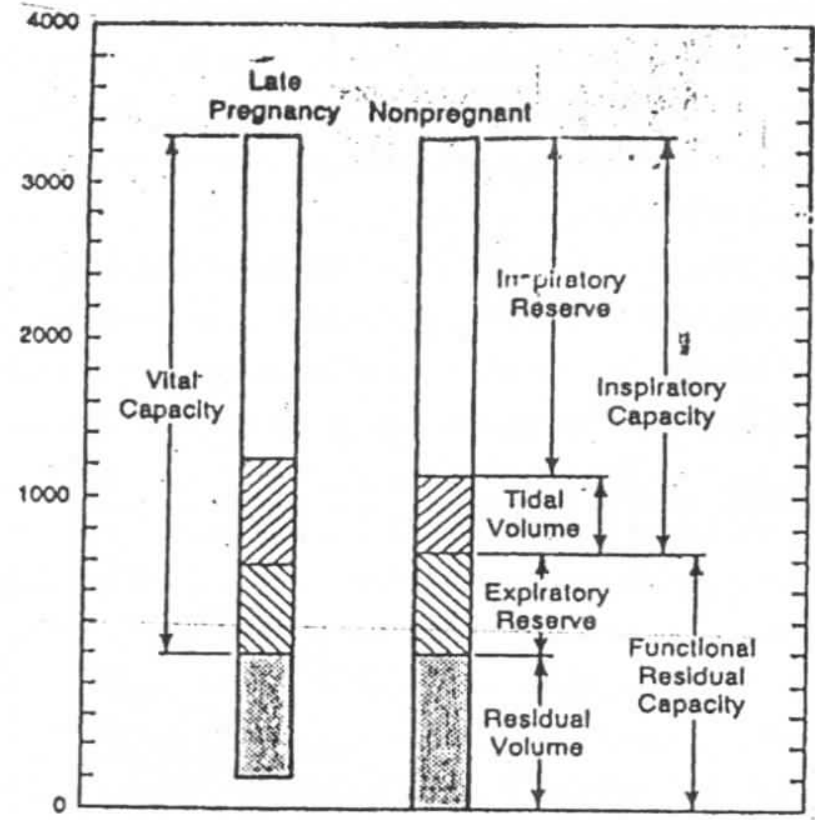

Gambar 2. Komponen Paru pada Keadaan Hamil dan Tidak (Wells, 1985: 132)

\section{Perubahan kardiovaskuler}

Perubahan kardiovaskuler terjadi pada awal masa kehamilan. Pertumbuhan uterus dan plasenta membuat kebutuhan akan aliran darah dan $\mathrm{O}_{2}$ naik. Keadaan itu membuat jantung bekerja lebih keras.

Pada kehamilan trimester pertama, curah jantung naik sekitar $20 \%$ di atas normal, sedangkan selama trimester ke dua dan ke tiga kenaikkannya lebih kecil. Kenaikkan curah jantung tersebut disebabkan oleh naiknya beart rate (HR) dan volume sekuncup (SV). Heart rate naik sekitar 15 denyut per menit, sedangkan volume sekuncup naik sekitar $10-12 \%$.

Perubahan tekanan darah hanya sedikit. Biasanya akan terjadi sedikit penurunan tekanan sistole dan diastole hingga sekitar minggu ke-22. setelah itu tekanan darah akan naik lagi sejalan dengan bertambahnya usia kehamilan. Secara umum, pada 
trimester ke tiga akan terjadi peningkatan aliran darah perifer sebagai akibat adanya vasodilatasi dan peningkatan distensibilitas vena. Lebih jauh, distensibilitas vena akan menyebabkan pelebaran vena pada anggota gerak bawah, vulva dan anus, ditambah lagi oleh penjepitan vena femorale, maka akan terjadi penghambatan aliran darah balik dari anggota gerak bawah. Untuk itu, dianjurkan bagi wanita hamil agar jangan berdiri tęlalu lama.

Pada paroh pertama masa kehamilan akan terjadi kenaikan volume darah dan penurunan kadar hematokrit, sedang pada paroh ke dua, pertambahan sel-sel darah merah lebih cepat dibanding penambahan plasma darahnya, sehingga nilai hematokrit akan naik. Secara umum, kehamilan akan menurunkan kadar hematokrit, karena biasanya penambahan plasma darah lebih cepat dibanding penambahan sel-sel darah merah. Namun demikian, jika simpanan zat besi cukup, maka sedikit penurunan hematokrit tidak akan menimbulkan masalah.

\section{Perubahan muskulo skeletal}

Karena pengaruh hormone relaksin, ligamenta yang mendukung sendi sacroiliaca dan sendi pubis menjadi lebih lunak/lembut dan teregang, sehingga rongga pelvis menjadi lebih luas dan dapat digerakkan (Ganong, 1989: 383). Relaksasi persendian mencapai ukuran maksimal pada trimester ke tiga. Perluasan rongga perut menyebabkan susunan ruas-ruas tulang belakang menjadi lebih lordosis, sementara pengendoran sendi sacroiliaca menyebabkan perluasan pelvis. Kedua hal tersebut menyebabkan timbulnya nyeri pinggang dan pergeseran titik berat badan. Lebih lanjut pergeseran titik berat badan kadang mengganggu keseimbangan.

Untuk mengatasi/mengurangi derita tersebut, para wanita hamil dapat melakukan latihan-latihan yang memperkuat otot-otot pinggang dan perut. Renang gaya dada juga baik bagi mereka.

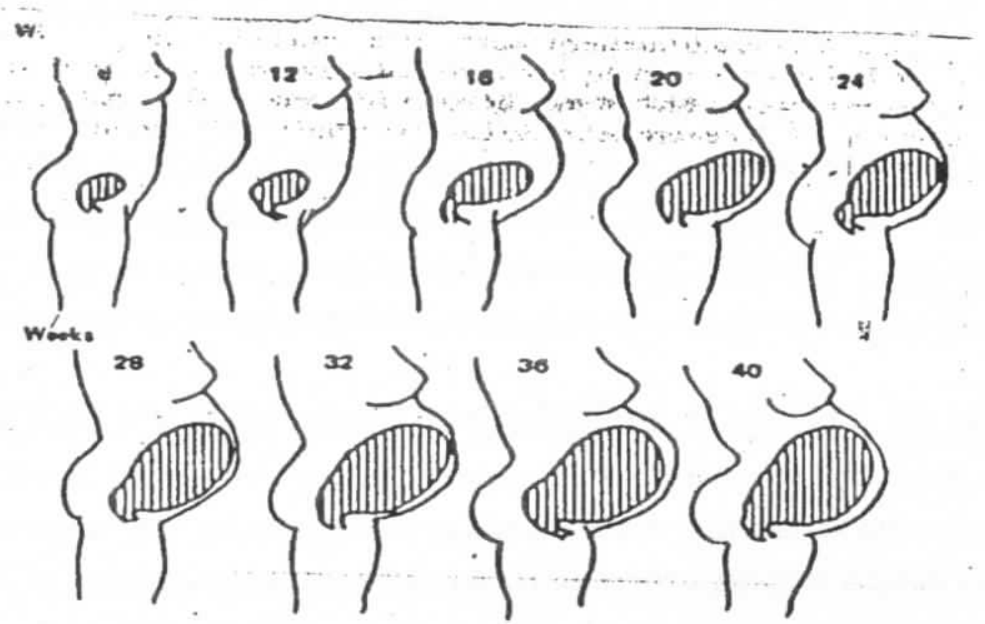

Gambar 3. Perkembangan Perubahan Postural Selama Hamil (Wells, 1985: 136) 


\section{Perubahan sistem syaraf pusat}

Pada trimester pertama, biasanya wanita hamil merasa malas atau cepat lelah. Mungkin peningkatan kadar progesterone menyebabkan terjadinya somnolence. Kadang juga disertai dengan mual (morning sickness). Kondisi tersebut akan membaik pada trimester ke dua. Pada trimester ke tiga, mereka mungkin akan mengalami depresi dan nyeri pinggang yang kronis. Namun demikian, masing-masing orang akan memberikan reaksi pada kehamilan yang berbeda.

\section{Perubahan system pencernaan dan saluran pencernaan}

Perjalanan makanan akan menjadi lebih lambat, yang mengakibatkan meningkatnya penyerapan air. Selanjutnya faeces menjadi lebih kering dan keras, akibatnya para wanita hamil sering mengalami sembelit. Pencernaan lemak menjadi lebih sulit karena pengosongan gall bladder lebih lambat.

Sebagian wanita hamil mengalami peningkatan nafsu makan, yang kemungkinan disebabkan adanya peningkatan rangsangan terhadap pusat kontrol nafsu makan di hypothalamus atau karena emosi. Kadang wanita hamil mempunyai keinginan yang besar terhadap suatu jenis makanan tertentu.

Pada saluran kencing (urinary tract) terjadi perubahan fungsi ginjal. Karena aliran plasma ke ginjal meningkat, maka penyaringan air juga meningkat. Masalah yang sering muncul adalah seringnya buang air kecil. Kadang juga terjadi infeksi saluran kencing yang disebabkan oleh vasodilatasi saluran dari ginjal ke bladder, sehingga urine tertahan lebih lama di situ.

\section{Perubahan hormonal}

Selama masa kehamilan, hormone steroid dihasilkan oleh "maternal-fetal-placental complex". Plasenta membuat beberapa macam estrogen dan juga dapat mengubah endrogen dalam sirkulasi menjadi estrogen. Sejalan dengan bertambahnya usia kehamilan kadar progesterone darah juga meningkat.

Pituitary yang menghasilkan gonadotropin dan hormone pertumbuhan dihambat, tapi kadar prolaktin meningkat (Weinreb, 1984: 811). Kadar hormone thyroid dan cortisol juga meningkat, seperti halnya kadar insulin dalam sirkulasi dan asam lemak bebas (Ganong: 1989: 384). Kehamilan normal diasosiasikan dengan "kebal insulin", sehingga sering diacu sebagai diabetagenis. Diabetes latent sering muncul saat hamil.

\section{PENGARUH OLAHRAGA TERHADAP PERUBAHAN FISIK}

Meskipun banyak perubahan fisik yang akan dialami oleh wanita hamil, namun belum tersedia laporan yang mencakup semua respon khusus masing-masing perubahan pada latihan. Berikut adalah respon beberapa unsur fisik terhadap latihan. 


\section{Pengaruh olahraga terhadap sistem respirasi}

Dari hasil tes ergometer bycicle diperoleh bahwa tidak ada perubahan kemampuan ambilan $\mathrm{O}_{2}$. Namun demikian, setiap beban latihan akan menyebabkan kenaikan ventilasi per menit dan menurunkan perbedaan kadar $\mathrm{O}_{2}$ antara arteri dengan vena.

Pada awal masa kehamilan, latihan akan menyebabkan bertambahnya frekuensi respirasi, nąmun pertambahan frekuensi akan menurun secara bertahap sejalan dengan bertambahnya usia kehamilan (untuk beban yang sama). Mungkin kenaikan volume tidal menyebabkan naiknya ventilasi per menit dan juga naiknya ambilan $\mathrm{O}_{2}$.

\section{Pengaruh olahraga terhadap kardiovaskuler}

Kehamilan dan latihan sama-sama meningkatkan curah jantung. Kehamilan menyebabkan naiknya beart rate (HR) istirahat, sementara latihan menurunkan beart rate istirahat. Sehingga jika wanita yang hamil itu kesegaran jasmani baik, maka reserve jantungnya akan relatif konstan. Kalau toh ada perubahan, maka perubahan itu adalah kecil. Reserve jantung $=$ volume sekuncup $\mathrm{x}$ (heart rate maksimal - heart rate istirahat).

Tabel 1. Perubahan Konsentrasi Butir-butir Darah Selama Hamil (Wells, 1985: 128)

\begin{tabular}{lccc}
\hline \multicolumn{1}{c}{ Parameter } & $\begin{array}{c}\text { Late } \\
\text { pregnancy }\end{array}$ & $\begin{array}{c}\text { Nonpregnant } \\
\text { state }\end{array}$ & $\begin{array}{c}\text { Percent } \\
\text { Increase }\end{array}$ \\
\hline Blood volume (ml) & 4820 & 3250 & 48 \\
RBC volume (cells/cu mm) & 1790 & 1355 & 32 \\
Hematocrit (\%) & 37.0 & 41.7 & 32 \\
\hline
\end{tabular}

Hingga minggu ke-25 atau ke-27, kenaikan curah jantung istirahat maksimal mencapai $40 \%$. Sementara pendapat lain menyatakan bahwa kenaikan curah jantung akan mencapai harga maksimal pada usia kehamilan 38-40 minggu. Selama masa kehamilan, heart rate akan naik, tapi volume sekuncup akan turun secara bertahap mulai minggu ke 20-24 hingga tiba masa persalinan.

Kenaikan curah jantung dan volume sekuncup pada olahraga dengan intensitas sedang akan berkurang dengan bertambahnya usia kehamilan. Penurunan reserve jantung akibat bertambahnya usia kehamilan menyebabkan pengumpulan darah pada vena perifer, yang selanjutnya juga akan mengurangi venous return (pengembalian darah ke jantung). Karena kerja jantung pada wanita hamil lebih berat, maka mereka sudah akan mencapai curah jantung maksimal pada latihan dengan intensitas yang lebih rendah.

\section{Pengaruh olahraga terhadap hormonal}

Seperti laporan Artal, Platt, Sparling, Kammula, Jilek dan Nakamura tahun 1980 seperti yang dikutip oleh Wells, dari penelitian atas 23 wanita hamil pada trimester 
pertama yang diberi olahraga sangat ringan. Orang coba melakukan jalan pelan di treadmill selama 15 menit. Diperoleh data bahwa oxygen uptake kurang dari 0.51 . $\min ^{-1}$ dan juga menaikkan kadar glucagons, norepinephrine, epinephrine naik secara nyata. Dengan pulih asal selama 30 menit, tidak ada perubahan kadar glucose dan cortisol, yang menunjukkan bahwa latihan lebih merangsang syaraf symphatis dibanding medulla adrenalis seperti juga pada wanita yang tidak hamil.

\section{PETUNJUK BEROLAHRAGA BAGI WANITA HAMIL}

Secara pasti belum ada laporan yang jelas yang menyatakan adanya kontraindikasi atas latihan selama kehamilan normal. Nampaknya, baik calon ibu maupun janinnya sudah dilengkapi sedemikian rupa, sehingga mampu mengatasi sedikit penurunan reserve jantung dan sedikit pengurangan aliran darah ke uterus yang disebabkan karena latihan.

Para wanita hamil harus memperhatikan sinyal-sinyal yang diberikan oleh tubuhnya. Sinyal tersebut dapat bermacam-macam, misalnya perdarahan vagina atau naiknya tekanan darah, nyeri atau pun tidak adanya gerakan janin. Jika salah satu dari sinyal itu muncul, latihan harus dihentikan dan segera diperiksakan. Mungkin juga akan dirasakan gejala yang lebih ringan, seperti timbulnya ketidaknyamanan di dalam latihan. Hal itu berarti latihan harus dikurangi durasinya, intensitasnya atau dihentikan sama sekali.

Bertambahnya berat badan dan perubahan struktur organ akan membuat wanita hamil mengalami kesulitan untuk melakukan latihan. Akibat perluasan rongga perut dan perluasan rongga pelvis akan menyebabkan pergeseran letak titik pusat berat badan dan nyeri pinggang. Sementara pergeseran letak titik pusat berat badan juga kadang menganggu keseimbangan tubuhnya. Latihan-latihan yang tepat selama masa kehamilan akan memperkuat otot-otot pinggul dan otot-otot perut, sehingga akan mengurangi derita sakit pinggul selama masa kehamilan.

\section{Latihan selama hamil}

Penelitian oleh Curet \& Collings tahun 1981 atas wanita hamil yang dilatih dengan cycling (berseri) pada $70 \%$ maximum oxygen uptake, yang diberi latihan 30 menit, $3 \mathrm{kali} /$ minggu selama 14 minggu. Kelompok kontrol yang tidak melakukan latihan dites secara periodik sepanjang masa kehamilan dan pada 6,5 minggu setelah melahirkan. Diperkirakan kelompok yang dilatih mengalami peningkatan maximum oxygen uptake sekitar $18 \%$ antara trimester II dan III dan menurun sekitar $16 \%$ antara trimester III - masa persalinan, saat tidak ada atau tidak melakukan latihan. Diperkirakan, kelompok kontrol mengalami peningkatan $2 \%$ pada tes di trimester III dan turun $21 \%$ setelah persalinan. Jika nilai maximum oxygen uptake dinyatakan persatuan berat badan, kelompok terlatih naik $8 \%$ dan kelompok kontrol turun $4 \%$ pada trimester III. Pada masa persalinan, subjek terlatih mengalami penurunan $7 \%$ per satuan berat badan dan kelompok kontrol turun $14 \%$. 


\section{Seberapa banyak latihan selama masa kehamilan}

Mestinya, untuk menentukan beban dan memilih jenis latihan berkonsultasi lebih dahulu dengan dokter atau ahli fisiologi. Masa kehamilan bukanlah masa yang tepat untuk memulai program latihan berat atau untuk menurunkan berat badan. Namun demikian, bagi mereka yang bukan atlet juga akan lebih baik untuk meningkatkan kesegaran jasmaninya melalui latihan.

Bagi atlet yang sangat terlatih, mereka dapat melanjutkan kegiatannya hingga kehamilannya memasuki usia 3 atau 4 bulan. Memasuki bulan ke lima dan ke enam, intensitas latihannya harus dikurangi. Misalnya jika biasanya melakukan jogging, maka lebih baik diganti dengan jalan cepat. Sementara memasuki bulan ke 7 sampai ke-9, latihannya diganti dengan latihan-latihan yang bersifat rekreatif. Jenis/macam olahraga yang dapat dijadikan pilihan bisa jogging, jalan cepat, senam atau renang.

Sebagai petunjuk untuk menentukan intensitas latihan, dapat mempergunakan beberapa cara sebagai berikut:

a. Maximal Heart Rate :

Heart Rate Reserve $=$ Heart Rate Maximal - Heart Rate Rest.

Seandainya HR rest $=65 \mathrm{detak} / \mathrm{mnt}$ dan HR max. $=200$, maka

HRRnya $=200-65=135 \mathrm{detak} /$ menit.

Target Heart Rate $=($ intensitas $\mathrm{x}$ HRR $)+$ HR rest.

Jika intensitas latihan yang akan dilakukan $=60 \%$, maka :

$60 \%$ THR $=(0.6 \times 135)+65$ (Fox, 1988).

b. Maximal Heart Rate

THR $=$ Intensitas $\times 200$, maka jika intensitas latihannya $60 \%$, THR $=0,6 \times 200$

$=120 \mathrm{detak} /$ menit. (Fox, 1988).

c. Maximl Heart Rate dengan memperhitungkan umur:

HR max. $=220-$ umur. Jika intensitasnya $60 \%$ maka

THRnya $=(220-$ umur $) \times 60 \%$ detak/menit $($ Fox, 1988).

\section{KESIMPULAN}

Setiap orang akan mempunyai pengalaman dan memberikan reaksi yang berbeda terhadap kehamilan yang mereka alami. Pengalaman dan reaksi wanita hamil dipengaruhi oleh beberapa faktor, yakni kepribadian, status gizi, pola hidup, hubungannya dengan orang tua dan keluarganya serta sikapnya terhadap kemungkinan hadirnya seorang anak.

Kehamilan adalah suatu fase krisis maturasi, yang konsekuensinya tidak mungkin untuk dihindari. Usaha yang dapat dilakukan hanyalah mengurangi derita yang akan dialami.

Salah satu cara yang dapat ditempuh guna mengurangi derita kehamilan dan persalinan adalah dengan melakukan olahraga atau latihan. Sebelum melakukan dan menentukan macam latihan, sebaiknya didahului dengan konsultasi pada dokter atau ahli fisiologi. Di dalam melakukan latihan, wanita hamil harus secara cermat membaca sinyal-sinyal yang diberikan oleh tubuhnya. Jika sekiranya latihan tersebut membuatnya kelelahan, maka 
intensitas atau durasinya perlu diturunkan. Jika ternyata gerakan-gerakan dalam latihan tersebut terlalu sulit untuk dilakukan, maka dapat diganti dengan latihan yang lain, yang lebih sederhana. Ada beberapa macam olahraga yang dapat dipilih, yakni jogging, jalan cepat, senam atau renang terutama gaya dada.

\section{DAFTAR PUSTAKA}

Fox, E.L. Bowers, R.V., Foss, M.L., (1988). The Physiological Basis of Physical Education and Athletics, Saunders College Publishing, Philadelphia.

Ganong, W.F., (1989). Review of Medical Physiolog., Appleton \& Lange, A Publishing Devision of Prentice-Hall, U.S.A.

Kuntaraf, J. dan Kuntaraf, K.L. (1992). Olabraga Sumber Kesehatan. Percetakan Advent Indonesia, Kotak Pos 1188, Bandung.

Previt, J.J. (1983). Human Physiology. McGraw-Hill, Inc. U.S.A.

Primadi Hasanah, (1977). Senam Hamil., Percetakan/Penerbit Elstar Offset, Bandung.

Sandelowski, M., (1981). Women, Health, and Choice, Prentice Hall., Inc. Englewood Clift, N.J. 07632.

Shangold, M.M., and Mirkin, G. (1988). Women and Exercise Pbysiology and Sports Medicine., F.A. Davis Company. Philadelphia.

Sumosardjuno, S., (1988). Petunjuk Praktis Kesehatan dalam Olabraga. P.T. Gramedia. Jakarta.

Stewart, A.C., and Koch, J.B., (1983). Children Development Through Adolescence. John Wiley \& Sons. Inc. Canada.

Weinreb, E.L., (1984). Anatomy and Physiology., Adison-Wisley Publishing Company, Inc. Canada.

Wells, C.L., (1985). Women, Sport and Performance: A Physiological Perspective. Human Kinetic Publisher, Inc. Compaign. Illinois. 